\title{
PENINGKATAN PRODUKSI USAHA TANI PADI DI KECAMATAN GUNUNGSARI MELALUI PENYULUHAN TEKNOLOGI PRODUKSI
}

\author{
Ridwan ${ }^{*}$, Lalu Wirasapta Karyadi, dan Nuning Juniarsih \\ Fakultas Pertanian Universitas Mataram \\ ${ }^{*}$ Korespondensi: ridwan5731@yahoo.com
}

Diterima 15 November 2018 / Disetujui 20 Desember 2018

\begin{abstract}
ABSTRAK
Kegiatan pengabdian ini bertujuan untuk melakukan diseminasi informasi (sosialisasi) dan advokasi tentang teknologi produksi dalam pelaksanaan. Pengabdian ini dilaksanakan di wilayah Kecamatan Gunungsari, yaitu di Desa Tamansari, sedangkan tempat kegiatan ditentukan berdasarkan kesepakatan antara Tim Penyuluh dengan Warga sasaran. Demikian juga waktu pelaksanaan kegiatan ditentukan berdasarkan kesepakatan. Pada hari-H kegiatan Tim mendatangi lokasi kegiatan tepat waktu. Materi penyuluhan disampaikan oleh seluruh anggota Tim secara bergiliran yang dilakukan dengan metode ceramah, diskusi, serta menggunakan model Pendidikan Orang Dewasa (POD). Hasil evaluasi menunjukkan bahwa peserta penyuluhan umumnya memiliki pemahaman yang baik terhadap materi yang disampaikan oleh Tim Penyuluh. Hal ini mengindikasikan tentang cukup efektifnya penyuluhan ini dalam upaya penyebarluasan informasi mengenai teknologi produksi padi dalam rangka pelaksanaan Program Upsus Pajale. Penggunaan metode ceramah dan diskusi dalam kegiatan penyuluhan ini memungkinkan terjadinya proses komunikasi dua arah antara narasumber dengan audiens secara langsung dan bertatap muka. Melalui tatap muka di kelas, audiens dapat menyampaikan pertanyaan, pendapat dan saran kepada para narasumber secara langsung dan para narasumber pun dapat memberikan umpan balik (feedback) secara langsung, sehingga terjadi komunikasi yang bersifat dialogis antara narasumber dengan para peserta, yang pada gilirannya komunikasi antara keduanya menjadi efektif. Hasil evaluasi juga menunjukkan bahwa respons peserta penyuluhan terhadap pelaksanaan penyuluhan ini tergolong positif. Umumnya peserta penyuluhan menilai bahwa baik metode, media maupun bahasa pengantar yang digunakan oleh para narasumber dalam kegiatan penyuluhan mendukung terwujudnya pemahaman yang baik bagi peserta penyuluhan itu sendiri mengenai materi yang disampaikan oleh Tim Penyuluh.
\end{abstract}

Kata kunci: teknologi produksi, program, upaya khusus

\section{PENDAHULUAN}

Beras merupakan bahan makanan pokok bagi umumnya penduduk Indonesia. Untuk memenuhi kebutuhan beras dari produksi dalam negeri, telah ditetapkan sasaran produksi padi tahun 2015 sebesar 73.400 .000 ton gabah kering giling (GKG). Banyak tantangan yang harus dihadapi untuk mencapai sasaran produksi 
tersebut. Oleh karena itu, diperlukan upaya peningkatan produksi yang luar biasa.

Berbagai upaya peningkatan produksi dan produktivitas usahatani padi telah dilaksanakan, antara lain melalui Sekolah Lapangan Pengelolaan Tanaman Terpadu (SL-PTT) sejak tahun 2008 dan melalui PTT atau peningkatan mutu intensifikasi pada tahun-tahun sebelumnya. Pelaksanaan SL-PTT sebagai pendekatan dalam mendorong peningkatan produksi padi nasional telah terbukti mengungkit pencapaian produksi, namun ke depan dengan berbagai tantangan yang lebih beragam maka diperlukan penyempurnaan dan peningkatan kualitas pada tatanan perencanaan dan operasionalisasi di lapangan.

Sejalan dengan hal tersebut diatas, maka sejak tahun 2015 upaya peningkatan produksi padi difokuskan pada kawasan tanaman pangan, melalui Gerakan Penerapan Pengelolaan Tanaman Terpadu (GP-PTT) dengan fasilitasi bantuan sarana produksi (saprodi), tanam jajar legowo dan pertemuan kelompok pada seluruh areal program GP-PTT sebagai instrument stimulan disertai dengan dukungan pembinaan, pengawalan dan pemantauan oleh berbagai pihak.

Sejalan dengan fasilitasi bantuan yang diberikan pemerintah pada seluruh areal program, maka luas GP-PTT Padi tahun 2015 adalah 350.000 ha, yang dialokasikan pada kawasan padi dan non kawasan padi dan terinci atas: Kawasan Padi inbrida seluas 75.000 ha, non Kawasan padi inbrida seluas 225.000 ha dan non Padi hibrida seluas 50.000 ha.

Dalam GP-PTT petani dapat langsung menerapkan teknologi budidaya spesifik lokasi yang merupakan hasil rekomendasi dari Balai Pengkajian Teknologi Pertanian (BPTP) setempat. Melalui GP-PTT petani akan mampu mengelola potensi sumberdaya yang tersedia secara terpadu dalam budidaya padi di lahan usahataninya spesifik lokasi, sehingga petani menjadi lebih terampil serta mampu mengembangkan usahataninya dalam rangka peningkatan produksi padi. Namun demikian wilayah di luar GP-PTT (pertanaman swadaya petani) harus tetap dilakukan pembinaan, pendampingan dan pengawalan sehingga produksi dan produktivitas tetap dapat meningkat, mengingat sasaran produksi yang telah ditetapkan meningkat dari tahun sebelumnya.

Dengan berbagai fasilitasi/stimulan yang diberikan pemerintah, diharapkan pelaksanaan GP-PTT Padi berbasis kawasan dan non kawasan dapat terlaksana dengan baik dan tepat sasaran sehingga dapat memberikan sumbangan terhadap peningkatan produksi dan produktivitas.

Kendala dalam peningkatan produksi padi yang semakin kompleks karena berbagai perubahan dan perkembangan lingkungan strategis diluar sektor pertanian berpengaruh dalam peningkatan produksi tanaman pangan.

Tantangan utama yang dihadapi dalam upaya peningkatan produksi padi adalah : 1) meningkatnya permintaan beras sesuai dengan peningkatan jumlah penduduk, 2) terbatasnya ketersediaan beras dunia, dan 3) kecenderungan meningkatnya harga pangan beras.

Disamping tantangan, upaya peningkatan produksi tanaman padi juga dihadapi sejumlah permasalahan, yaitu antara lain : 1) meningkatnya kerusakan lingkungan dan perubahan iklim global, 2) terbatasnya ketersediaan infrastruktur, 3) 
belum optimalnya sistem perbenihan nasional, 4) terbatasnya akses petani terhadap permodalan dan masih tingginya suku bunga usaha tani, 5) masih lemahnya kapasitas kelembagaan petani dan penyuluh, 6) meningkatnya alih fungsi lahan pertanian ke penggunaan non pertanian, serta 7) kurang harmonisnya koordinasi kerja antar sector terkait pembangunan pertanian. Disamping itu, pembangunan pertanian selama ini masih dilaksanakan tersekat-sekat oleh batasan administratif serta berorientasi pada kegiatan-kegiatan yang tidak mampu menjadi faktor pengungkit untuk pencapaian sasaran pembangunan pertanian.

Disamping tantangan dan permasalahan yang dihadapi dalam upaya peningatan produksi tanaman pangan, terutama padi, terdapat sejumlah peluang yang apabila dimanfaatkan dengan baik akan memberikan kontribusi pada upaya peningkatan produksi. Peluang tersebut antara lain : 1) kesenjangan hasil antara potensi dan kondisi di lapangan masih tinggi, 2) tersedia teknologi untuk meningkatkan produktivitas, 3) potensi sumberdaya lahan sawah, rawa/lebak, lahan kering (perkebunan, kehutanan) yang masih luas, 4) pengetahuan/Keterampilan SDM (Petani, Penyuluh/PPL, POPT, Pengawas Benih Tanaman/PBT, dan Petugas Pertanian Lainnya) masih dapat dikembangkan, 5) tersedianya potensi pengembangan produksi berbagai pangan pilihan selain beras, 6) dukungan Pemerintah Daerah, dan 7) ketersediaan sumber genetik.

Dengan memperhatikan peluang dan tantangan yang ada bahwa dalam upaya meningkatkan produksi dan produktivitas usahatani padi dinilai penting untuk dilakukan penyuluhan tentang teknologi produksi dalam pelaksanaan Program Upaya Khusus (Upsus) Peningkatan Produksi usahatani padi di Kecamatan Gunungsari.

\section{METODE KEGIATAN}

Memperhatikan permasalahan yang ada maka kerangka pemecahan masalah yang diusulkan untuk dilaksanakan dalam kegiatan pengabdian pada masyarakat ini adalah memberikan penyuluhan kepada petani agar petani memahami teknologi produksi padi dalam kerangka pelaksanaan program Upaya Khusus (Upsus) peningkatan produksi padi, dan pada gilirannya petani menerapkan teknologi produksi dimaksud, sehingga produksi dan produktivitas usahatani padi meningkat sesuai harapan.

Kegiatan Pengabdian Kepada Masyarakat ini akan dilakukan menurut rencana dan jadwal yang akan ditetapkan kemudian. Dalam pelaksanaan kegiatan pengabdian ini digunakan metode dan media yang disesuaikan dengan kondisi sasaran. Dalam hal ini Tim penyuluh nantinya akan menyampaikan materi penyuluhan menurut jadwal waktu yang telah ditetapkan dan disepakati dengan peserta sebagai sasaran penyuluhan. Seluruh anggota tim penyuluh adalah dosen pada Fakultas Pertanian Universitas Mataram yang telah berpengalaman dan berkompeten dalam melakukan kegiatan kegiatan pengabdian pada masyarakat. Materi yang disampaikan, tentu saja, adalah yang sesuai dengan topik dan tujuan yang ingin dicapai dalam kegiatan pengabdian pada masyarakat ini. Kemudian diskusi dan dialog akan dibuka untuk memberikan kesempatan kepada para peserta untuk menyampaikan pertanyaan, masalah yang dihadapi terkait 
dengan materi yang disampaikan oleh para penyuluh.

Sasaran utama kegiatan pengabdian kepada masyarakat ini adalah para petani. Namun, untuk maksud agar supaya inovasi ini dapat menyebar secara lebih meluas dan lebih cepat maka sejumlah aparat desa, tokoh masyarakat, tokoh adat dan tokoh agama setempat dilibatkan sebagai peserta. Diharapkan peserta yang memperoleh materi penyuluhan tersebut selanjutnya akan menularkan pengetahuan yang diperolehnya kepada pihak lain, terutama petani, sehingga pada gilirannya para petani di daerah tersebut memiliki pemahaman tentang teknologi produksi padi dalam kerangka pelaksanaan program Upsus Padi.

Pengabdian pada masyarakat ini dilakukan di wilayah Kecamatan Gunungsari, yaitu di Desa Tamansari. Sedangkan tempat kegiatan ditentukan berdasarkan kesepakatan antara Tim Penyuluh dengan Kepala Dusun, Ketua Kelompok Tani dan tokoh masyarakat serta warga sasaran. Demikian juga waktu pelaksanaan kegiatan juga ditentukan berdasarkan kesepakatan. Pada hari-H kegiatan Tim Penyuluh mendadatangi lokasi kegiatan secara tepat waktu. Materi penyuluhan disampaikan oleh semua anggota Tim Penyuluh yang dilakukan dengan metode ceramah, diskusi, serta pembimbingan. Sedangkan alat bantu yang digunakan adalah papan tulis, kertas manila, LCD, wereless, dan lain-lain.

\section{HASIL DAN PEMBAHASAN}

Tujuan dari setiap kegiatan penyuluhan adalah perubahan perilaku sasaran, baik pada ranah kognitif, afektif maupun psikomotorik. Perubahan perilaku pada ranah kognitif dan afektif dapat diketahui segera setelah seluruh rangkaian kegiatan penyuluhan selesai dilakukan. Perilaku kognitif berwujud pemahaman terhadap materi penyuluhan yang disampaikan oleh Tim Penyuluh. Oleh karena itu maka keberhasilan penyuluhan di sini diukur dengan menggunakan indikator pemahaman peserta penyuluhan mengenai teknologi produksi padi dalam kerangka pelaksanaan Program Upsus Pajale.

Kegiatan penyuluhan ini dilakukan dengan metode audiensi (ceramah dan tanya jawab). Tujuannya adalah untuk menyebarluaskan informasi mengenai teknologi produksi dalam pelaksanaan program upaya khusus (upsus) peningkatan produksi padi. Di samping itu, penyuluhan ini bertujuan untuk mengadvokasi para petani melalui pendekatan yang edukatif dan persuasif untuk menerapkan teknologi tersebut yang disosialisasikan melalui kegiatan penyuluhan ini. Kegiatan penyuluhan ini dilaksanakan di rumah Kepala Dusun Medas, Desa Tamansari pada tanggal 18 dan 19 September 2018. Jumlah peserta penyuluhan 20 orang, sebagaimana ditunjukkan dalam daftar hadir (LAMPIRAN 2). Kemudian di ujung acara dilakukan evaluasi formatif yang bertujuan untuk mengetahui kemampuan kognitif para peserta penyuluhan dalam memahami materi yang telah disampaikan oleh Tim Penyuluh, dengan menggunakan instrumen yang telah disiapkan sebelumnya (LAMPIRAN 3)

Selanjutnya, melalui peserta penyuluhan ini semua informasi terkait teknologi produksi padi dalam rangka pelaksanaan Upsus Pajale diharapkan dapat menyebar secara snowball kepada 
warga masyarakat lainnya, terutama kepada petani, sehingga pada gilirannya akan menyebar ke seluruh petani yang ada di daerah tersebut, dan pada akhirnya mereka dapat menerapkannya seperti yang diharapkan.

Evaluasi yang dilakukan terhadap peserta penyuluhan adalah mengenai: (1) tingkat pemahaman mereka terhadap materi penyuluhan yang disampaikan oleh narasumber, dan (2) penilaian tentang pelaksanaan penyuluhan itu sendiri serta tanggapan mereka tentang kemungkinan penerapannya dalam melaksanakan usahatani padi pada Program Upsus Pajale.

Hasil evaluasi formatif menunjukkan bahwa peserta penyuluhan umumnya memiliki pemahaman yang baik terhadap materi yang disampaikan oleh Tim Penyuluh. Hal ini mengindikasikan tentang efektifnya penggunaan metode ceramah dan tanya jawab sebagai metode penyuluhan yang dipakai oleh Tim Penyuluh dalam upaya penyebarluasan informasi mengenai teknologi produksi padi di wilayah Kecamatan Gunungsari. Efektifnya metode ini terutama disebabkan karena terjadinya proses komunikasi dua arah antara Tim Penyuluh dengan peserta penyuluhan, sebagai audiens, secara langsung dan bertatap muka. Melalui tatap muka di kelas, audiens dapat menyampaikan pertanyaan, pendapat dan saran kepada Tim Penyuluh secara langsung dan Tim Penyuluh pun dapat memberikan umpan balik (feedback) secara langsung pula, sehingga terjadi komunikasi yang bersifat dialogis antara narasumber dengan para audiens, yang pada gilirannya komunikasi antara kedua belah pihak menjadi efektif. Sebaran peserta penyuluhan menurut tingkat pemahamannya tentang teknologi produksi padi ditunjukkan pada Gambar 1:

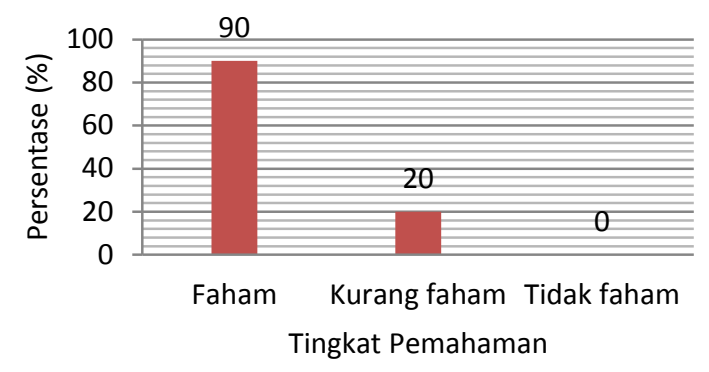

Gambar 1. Sebaran jumlah peserta penyuluhan (\%) menurut tingkat pemahamannya terhadap materi penyuluhan

Gambar 1 di atas menunjukkan bahwa sebagian besar peserta penyuluhan memiliki pemahaman dengan katagori faham dan hanya sebagian kecil yang tergolong kurang faham, sementara tidak ada seorang pun peserta dengan katagori tidak faham. Hal ini menunjukkan bahwa umumnya peserta audiensi memahami dengan baik materi yang disampaikan para narasumber. Dengan kata lain, peserta penyuluhan umumnya memahami teknologi produksi usahatani padi yang disampaikan oleh Tim penyuluh.

Selain dilakukan evaluasi pemahaman peserta penyuluhan terhadap materi yang disampaikan oleh para narasumber juga telah dilakukan evaluasi tentang respons mereka mengenai pelaksanaan penyuluhan itu sendiri dan respons mereka tentang kemungkinan penggunaan mekanisme penyelesaian konflik tersebut di kalangan mereka. Evaluasi tentang respons ini dilakukan dengan menggunakan model Likert yang dimodifikasi. Dalam hal ini setiap peserta diminta untuk memberikan penilaian/ tanggapan (setuju, ragu-ragu, atau kurang setuju) terhadap setiap pernyataan yang diajukan untuk dinilai. 
Hasil evaluasi menunjukkan bahwa umumnya peserta penyuluhan memiliki respons yang positif terhadap pelaksanaan penyuluhan yang dilakukan oleh Tim Penyuluh dalam rangka sosialisasi teknologi produksi usahatani padi dalam rangka pelaksanaan Progran Upsus Pajale. Sebaran peserta penyuluhan menurut respons-nya terhadap pelaksanaan penyuluhan ditunjukkan pada Gambar 2:

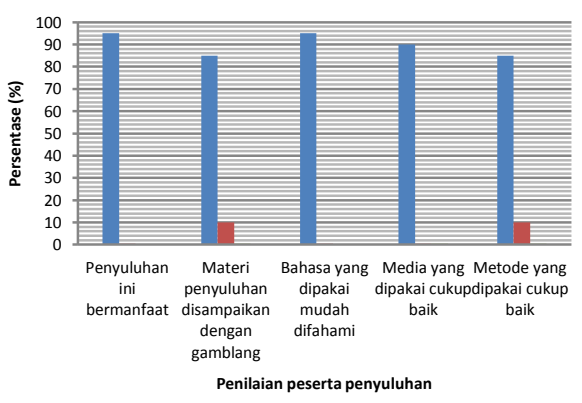
- Kurang setuju - Tidak setuju

Gambar 2. Jumlah peserta (\%) menurut respons-nya tentang pelaksanaan penyuluhan

Gambar 2 menunjukkan bahwa ratarata di atas $90 \%$ peserta memberikan tanggapan dengan menyatakan setuju pada setiap pernyataan yang diminta untuk ditanggapi terkait pelaksanaan penyuluhan yang dilakukan oleh Tim Penyuluh. Peserta penyuluhan menilai bahwa materi yang disampaikan oleh para narasumber bermanfaat bagi petani, karena dengan adanya sosialisasi ini mereka menjadi memahami tentang penerapan teknologi produksi usahatani padi dalam rangka pelaksanaan Program Upsus Pajale.

Peserta penyuluhan menilai bahwa bahasa pengantar, media, maupun metode yang digunakan oleh narasumber dalam kegiatan sosialisasi ini sangat mendukung untuk difahaminya dengan baik materi yang disampaikan oleh para narasumber. Oleh karena itulah maka peserta penyuluhan umumnya juga menyatakan setuju untuk menerapkan teknologi produksi usahatani padi yang disampaikan oleh Tim penyuluh.

Dari hasil pemantauan yang dilakukan bahwa selama kegiatan audiensi peserta memiliki antusiasme yang cukup tinggi serta memberikan respons yang positif terhadap kegiatan sosialisasi yang dilaksanakan oleh Tim Penyuluh. Hal ini antara lain ditunjukkan oleh banyaknya pertanyaan, tanggapan, dan masukan yang diberikan oleh para peserta pada sesi diskusi dan tanya jawab. Dalam merealisasikan kegiatan ini yang menjadi kendala penting adalah waktu pelaksanaan penyuluhan.

Adanya berbagai kesibukan warga dalam menjalani rutinitas pekerjaan sehari-hari menjadi salah satu kendala untuk menghadiri kegiatan penyuluhan. Namun berkat adanya upaya konfirmasi waktu yang intens kepada warga calon peserta penyuluhan yang dilakukan oleh Tim Penyuluh dan dibantu oleh aparat desa setempat maka masalah waktu ini dapat teratasi. Hal ini dibuktikan oleh hadirnya seluruh peserta audiensi yang diundang untuk mengikuti kegiatan penyuluhan, dan peserta yang hadir sesuai pula menurut komposisi yang telah direncanakan dan ditetapkan sebelumnya. Namun demikian pada setiap acara audiensi ada beberapa orang peserta hadir setelah beberapa saat acara dimulai.

\section{KESIMPULAN DAN SARAN}

\section{Kesimpulan}

Kegiatan penyuluhan ini tergolong efektif. Umumnya peserta penyuluhan memahami dengan baik teknologi produksi padi yang disampaikan oleh Tim Penyuluh melalui kegiatan penyuluhan ini. 
Respons para peserta penyuluhan terhadap pelaksanaan penyuluhan itu sendiri tergolong positif. Umumnya peserta penyuluhan menilai bahwa baik metode, media maupun bahasa yang digunakan oleh Tim Penyuluh dalam kegiatan penyuluhan mendukung terwujudnya pemahaman yang baik bagi peserta penyuluhan

\section{Saran}

Untuk menjangkau sasaran yang lebih luas kegiatan penyuluhan seperti ini secara bertahap perlu dilakukan di semua desa di mana usahatani padi dilaksanakan, khususnya di wilayah Kecamatan Gungsari dan umumnya di Kabupaten Lombok Barat.

\section{DAFTAR PUSTAKA}

Anonim, 2015. Pedoman Teknis GP-PTT Padi. Direktur Jenderal Tanaman pangan Kementerian Pertanian Republik Indonesia. Jakarta.

Anonim, 2015. Pedoman Umum Upaya Khusus Produksi Padi, Jagung dan Kedelai melalui Program Perbaikan Jaringan irigasi dan Sarana Pendukungnya. Jakarta.

Busyra dkk, 2016. Dampak program Upsus Pajale terhadap Perekonomian Kabupaten Tanjung Jawa Timur. Jurnal Media Agribisnis, Vol.1 No.1.

Jaizah, Y., 2018. Studi Pelaksanaan Program Upsus Pajale Komoditas Padi di Kecamatan Matarm Kota Mataram. Skripsi.

Husna, F., 2016. Studi Pelaksanaan Program Upaya Khusus Peningkatan Produksi Padi, Jagung, dan kedele (Upsus Pajale) di
Kecamatan Kediri Kabupaten Lombok Barat. Mataram. 